\title{
Uniformly Protecting U.S. Workers From the Health Risks of Second-Hand Smoke EXPOSURE
}

\section{By Kara Danielle Majkut Ryan}

Abstract: A preponderance of evidence conclusively demonstrates the severe health risk posed by secondhand smoke, or environmental tobacco smoke (ETS). While this evidence has led to the passage of indoor smoking bans in office buildings and many other indoor public places, in many states, workers in the hospitality industry still face toxic second-hand smoke every time they go to work. This article argues that policymakers must develop comprehensive smoke-free legislation for all indoor public spaces, including all indoor workplaces. Contrary to the arguments put forth by restaurant and tobacco industry interest groups, indoor smoking bans significantly diminish public health risks, provide equitable protection for all workers, increase healthcare and productivity savings, and have minimal, if any, negative economic impact on businesses and overall tax revenues. Washington, D.C. 's experience illustrates how policymakers can pass this vital public health legislation despite procedural roadblocks and interest group politics.

Second-hand smoke is toxic. With every breath of second-hand smoke, we inhale poisons and carcinogens that permeate and potentially devastate our cells, tissues and organs. 'These substances increase our chances of developing asthma, heart disease, and various kinds of cancer. Increased exposure equals increased risks.

For millions of Americans, exposure to secondhand smoke (also called environmental tobacco smoke, or "ETS") is not purely a personal choice or something easily avoided. As scientific evidence showing the dangers of second-hand smoke mounted in the late 1980 s and early 1990s, policymakers mandated that owners of office and retail buildings either provide separate enclosed smoking areas or ban smoking indoors altogether. However, many bar and restaurant workers still lack protection from ETS in the

Kara Danielle Majkut Ryan is a second-year graduate student in public policy at the George Washington University in Washington, D.C. Interested in housing and poverty issues, Kara is concentrating in urban studies. Ms. Ryan currently works as a research assistant at the Campaign Finance Institute in Washington, D.C., where she studies complex nonprofit organizations and their role in state and federal elections. She graduated with honors in 2001 from Wheaton College in Norton, Massachusetts, with a B.A. in political science. workplace. These "hospitality industry" employees are disproportionately exposed to E'TS on the job, substantially increasing their health risks with every shift they work, By failing to pass comprehensive smokefree legislation, policymakers effectively tell these workers that, unlike society's higher earners, they must choose between their occupation and their health. Policymakers should act now to provide bar and restaurant workers with the same occupational protection from ETS that teachers, scientists, doctors and lawyers enjoy.

This article atgues that policymakers must develop comprehensive smoke-free legislation for all indoor public spaces, including all indoor workplaces. Contrary to the arguments put forth by the restaurant and tobacco industries, indoor smoking bans significantly diminish public health risks, provide equitable protection for all workers, increase healthcare and productivity savings, and have minimal, if any, negative economic impact on businesses and overall tax tevenues. First, the article summarizes the scientific evidence conclusively proving that ETS is a severe health risk, especially for those in the hospitality industry, which merits government intervention. Next, the article demonstrates how a national ban would result in significant healthcare and productivity savings. To illustrate the benefits of smoking bans, the article also examines localities that have adopted smoke-free 
legislation. Finally, the article explores how special interests have continuously tried to block these policies, using Washington, D.C. as a case study.

\section{BACKGROUND: SMOKE-FREe LegISLATION}

\section{RISES IN PopULARITY}

Over the past decade, smoke-free policies as well as their public health and economic impacts have been the subject of ardent debate. Before California adopted the first statewide smoke-free policy, smoking bans were generally limited to cities and counties and often exempted stand-alone bars. Opponents largely thwarted more expansive bans by claiming that such policies would cause as much as a 30 percent drop in the hospitality industry's profits (Glantz and Smith 1997). As experts reviewed the economic data, however, they found that smoke-free policies had not significantly damaged restaurant industry revenues. One comparative study found that smoke-free laws actually increased profits (Alamar and Glantz 2004). Reassured that smoking bans did not cripple the economy, governments inside and outside the United States (U.S.) have been reexamining their laws governing workplace ETS exposure. Wendy Koch reported in USA Today on December 28, 2005 that by the end of 2005, over 2000 state and local governments in the U.S. had restricted smoking in public spaces. Koch added that this coverage translates to ETS protection for 39 percent of all Americans. Of these laws, 118 are comprehensive workplace smoking bans.

This policy trend has not been limited to the U.S. Radio Telefis Eireann reported on December 10, 2004 that over the past year, Ireland, Norway and New Zealand became the first nations to adopt a universal policy banning indoor smoking in public spaces. In January 2005, Italy also implemented nationwide smoke-free legislation (Gallus et al. 2005). On Januaty 1, 2006, Mark Roman of the Associated Press reported that Spain's nationwide smoke-free workplace policy took effect that day. The Nem York Times' Alan Cowell reported on February 15, 2006 that the British Patliament passed legislation banning smoking in public places. Along with Northern Ireland and Scotland, England's smoke-free law will take effect in early 2007. According to Cowell, the Welsh legislature is also considering smoke-free legislation. In addition, Reuters reported on April 1, 2006 that Bermuda implemented its indoor smoking ban that day; after a six-month grace period, authorities will enforce the law with fines and prosecution.

The smoke-free legislation trend continues to grow as policymakers around the world recognize that they can protect the public from involuntary workplace exposure to ET'S without triggering the dire economic losses predicted by ban opponents. The preponderance of evidence supporting comprehensive smoking bans, including arguments on grounds of public health, equity, healthcare cost savings and economic livelihood, has fueled the increasing rates of adoption in localities around the globe.

\section{The Public Health Argument: No Safe Level of Second-Hand Smoke}

\section{ExPOSURE}

Inhaled cigarette smoke contains more than 4,000 substances, over 200 of which are classified as poisons and over 50 of which are known carcinogens (ACS 2005). In 1986, a landmark U.S. Surgeon General's report first warned that the dangers of smoking are not limited to the user (HHS 1986). Everyone breathing the immediate smoky air absorbs the emitted toxins. Similar in chemical composition to the smoke inhaled directly through the cigarette, ETS is comprised of both "mainstream" smoke exhaled by the smoker during puffing and "sidestream" smoke released by the smoldering tobacco (HHS 2005a; IARC 2002). In 1993, the EPA classified ETS as a Class $A$ carcinogen, indicating sufficient evidence to infer a causal relationship between ETS and cancer (EPA 1994; EPA 1992). ETS shares this designation with only fifteen other substances, including radon and asbestos. Of this group, only ETS has actually been documented as causing cancer at "typical" exposure levels (IARC 2002; EPA 1994). . Although, the government regulates some hazardous substances to minimize health risks, this course of action would be inappropriate for ETS since experts 
believe that there is no safe level of exposure (ACS 2004; EPA 1994).

Researchers have conclusively linked cancer development with ETS exposure. The body's enzymes activate certain chemicals in ETS that can become carcinogenic when absorbed by a cell's DNA. Experts estimate that 3,000 Americans die from cancer caused by ETS each year. Linked primarily with lung cancer, ETS has also been associated with nasal sinus cancer and might also be related to cancers of the breast, cervix and bladder (NCI 2005). The EPA analyzed 14 studies of ETS exposure-response trends, ten of which found statistically significant links between increased levels of ETS exposure and cancer development. The EPA reports that "the probability of this [result] happening by chance is less than [one] in a billion" (EPA 2005) (emphasis in original).

ETS has also been associated with other serious health problems, such as an elevated risk of heart disease and the development of asthma and other respiratory problems (ACS 2004). The World Health Organization estimates that between 35,000 and 62,000 U.S. deaths are annually attributable to second-hand smoke, which is 15 times more deaths than those caused by E'TS-related lung cancer. As the World Health Organization explains, chemicals poison the cardiovascular muscle and vessels and cause blood to become "stickier" (Smoke At Work n.d.). One study followed more than 4,700 men from 24 British cities over two decades, measuring their blood cotinine (metabolized nicotine) levels and the incidence of heart disease and strokes. Researchers found that high levels of cotinine were associated with a 50-60 petcent increased risk of coronary heart disease. The researchers concluded that previous studies underestimated the health risks of ETS by failing to consider workplace exposure (Whincup et al. 2004). Finally, the $B B C$ reported on December 20, 2005 that a new Cambridge University study linked second-hand smoke with age-related macular degeneration, often resulting in blindness. The evidence clearly demonstrates that, each and every time people are exposed to this toxic substance, ETS increases the risks of developing life-threatening medical conditions.

\section{The Equity Argument: Hospitaltty} WORKERS DISPROPORTIONATELY SUFFER

\section{FROM ETS EXPOSURE}

As the health dangers of ETS exposure have emerged over the last two decades, local, state and national governments have passed legislation that restricts smoking in certain settings. Many of these policies have allowed employers to decide whether to ban smoking on the premises altogether or to only allow smoking in designated ateas. In practice, this policy has offered unequal protection to employees. While over 80 percent of legal, medical, research, and teaching professionals are protected from ETS toxins at work, smoke-free policies cover just 52 percent of blue-collar workers (Shopland et al. 2004). Food preparation and service employees, who earn much less than most office workers, ${ }^{3}$ enjoy the least protection. Only 43 percent of people in this sector work in smoke-free environments (Shopland et al. 2004).

Research confirms that restaurant servers inhale more second-hand smoke at work than they would in an office setting or even in a smoker's home. Researchers estimate that ETS levels in restaurants are 1.6 to 2.0 times higher than levels in offices and 1.5 times higher than in homes with at least one tobacco user (HHS 2005a). In bars, these figures soar. Bars have ETS levels that are 3.9 to 6.1 times higher than in offices and 4.4 to 4.5 times higher than in smokers' residences (HHS 2005a). One 2004 study measured the two types of cancer-causing particles present in the air along busy highways polluted by diesel and exhaust emissions and compared these particle levels to those measured in smoky bars and casinos (Repace 2004). In eight Delaware bars, the average level of "respirable particles," or airborne soot tiny enough to penetrate the lungs, was 231 micrograms per cubic meter of air. USA Today reported on September 20, 2004 that this level is 15 times the EPA's outdoor air cap and 49 times higher than average rush-hour levels on U.S. Interstate 95 , one of the nation's busiest highways.

Since the risk of serious health problems rises with higher levels of ETS exposure, experts believe that bar and restaurant employees are more vulnerable to 
E'TS-related diseases and disorders than workers outside the hospitality industry. An early study strongly suggested that food service workers are up to 50 percent more likely than the general population to develop lung cancer (Siegel 1993). Later studies confirm this finding. For example, researchers at the University of Minnesota Health Center conducted a study of non-smoking employees of bars or restaurants with smoking sections. They found that the participants had considerably higher levels of toxins in their urine on work days (Tulunay et al. 2005). On May 10, 2005, University of Minnesota Health Center representatives Sara E. Buss and Jonell Russinko issued a statement reporting that on work days, the employees' urine contained 25 times more nicotine and 4.5 times more NNAL, a byproduct of the carcinogen NNK found in tobacco smoke. NNAL levels persisted even on days participants did not work, indicating that the chemicals linger long after direct exposure has ended (Buss and Russinko 2005). While their findings cannot be generalized without more research, these studies illustrate the gravity of the problem: servers and bartenders in smoke-filled environments work under unsafe conditions.

Fearing the loss of smokers' patronage, the hospitality industry has been particularly hesitant to ban smoking outright. Instead; most bars and restaurants offer designated smoking areas: patrons choose whether they wish to dine in smoking or non-smoking sections. Unfortunately, this designation only protects non-smoking patrons. Servers, bartenders, busboys and hosts who wait on smokers inhale a shift's worth of second-hand smoke. Only 28 percent of wait staff and 13 percent of bartenders work in smoke-free settings (Shopland et al. 2004; ACS et al. 2004). Establishments often have no real boundary between smoking and non-smoking sections, further compounding the problem. Under these circumstances, legal compliance proves to be only nominal. Governments must intervene on behalf of all citizens to address the failure of private enterprise to voluntarily minimize a serious public health risk. Universal bans provide the best mechanism by which policymakers can correct the disparate impact of traditional smoking restrictions.

\section{The Healthcare Savings Argu-}

\section{MENT: ETS Costs U.S. BILLIONS}

In addition to endangering public welfare, ETSrelated health conditions drain the nation's economic resources by contributing to the multi-billion dollar price tag for health care associated with smokingrelated diseases. Researchers at the Center for Disease Control (CDC) estimate that the cost of smokingrelated adult health care was $\$ 75.5$ billion in 1998 . In addition to medical costs incurred, health conditions associated with smoking cost employers millions in lost productivity. The CDC computes that a smoker annually costs her employer $\$ 3,383 ; \$ 1,760$ in lost productivity and $\$ 1,623$ in excess medical expenses. After including an additional $\$ 81.9$ billion in lost productivity, the CDC tallies total smoking-related costs in 1998 at $\$ 157$ billion (CDC 2002). Thus, these smoking-related productivity losses and medical expenses take a harsh toll on the national economy.

A groundbreaking study by the Society of Actuaries offers the first estimate of the medical and economic losses attributable to ETS exposure (Behan et al. 2005). Rather than simply extrapolating effects based on smokers' data, the researchers conducted an extensive analysis of peer-reviewed studies that measured actual effects of exposure to ETS. They contend that "[w]hether ETS is the primary cause or aggtavates the disease...the cost increases and economic effects estimated in this paper would not be incurred but for exposure to ETS" (Behan et al. $2005,3)$. Behan, Eriksen and Lin identify the economic costs of ETS as direct medical costs, disability costs, and opportunity costs of unpaid caregivers. ${ }^{4}$ Considering the percent of the U.S. population exposed to ETS (22.96 percent), a condition's rate of occurrence per 100,000 exposed individuals and the medical costs associated with treatment, the study calculates the direct medical costs of ETS at $\$ 4.98$ billion. The researchers estimate the total cost of lost economic productivity to be $\$ 4.68$ billion. ${ }^{5}$ In addition to the $\$ 150$ billion price tag associated with active smoking, this study estimates that passive smoking annually costs the U.S. economy nearly $\$ 10$ billion (Behan et al. 2005).

Research also shows that worker health improves soon after workplace bans are enacted. One study 
examined the effects of California's smoking ban on the health of bartenders (Eisner et al. 1998). The researchers observed statistically significant improvements in both respiratory health and reported sensory irtitations after just one month. On October 18, 2005, Liz Szabo reported in USA Today that an analysis of Ireland's bar workers one year after the implementation of national smokefree legislation found that cotinine levels in nonsmoking bar employees fell by 80 percent. Szabo also notes that levels in neighboring Northern Ireland, which will implement a universal ban in 2007 , had fallen by only 20 percent. Another study analyzed indoor air quality in seven Boston bars and pubs before and after a universal smoking ban was implemented. It measured two features of ETS particles: respirable particles (RSPs) and particulate polycyclic aromatic hydrocarbons (PPAHs), carcinogenic compounds also associated with heart disease and stroke. After the enactment of the ban, indoor RSP levels fell by $90-95$ percent and PPAH levels fell by 80-90 percent (Repace n.d.). The CDC likewise measured indoor air quality in 20 bars, restaurants, bowling alleys, and bingo halls in western New York. It determined that RSP levels decreased by 84 percent after the statewide smokefree law took effect (CDC 2004). Compelling evidence shows that even if smoke-free laws are not met with 100 percent compliance, universal workplace bans still substantially reduce worker exposure to the harmful chemicals in ETS.

Additional studies have credited smoke-free policies with reducing the incidence of heart attacks. For instance, in the six months after a citywide smoking ban was enforced in Helena, Montana, the city experienced a 40 percent drop in hospitalizations for cardiac arrest (Sargent et al. 2004). The Pueblo City-County Health Department released a statement on November 14, 2005, announcing that cardiac arrest hospitalizations decreased by 27 percent in Pueblo, Colorado during the 18 months following the implementation of a smoke-free ordinance. Because of the relative isolation of these two cities, local hospitals capture all emergency patients; this factor boosts the studies' reliability. However, these reports do have their limitations. For example, no comparison group was available (Surindran 2004), only hospitalizations were counted (as opposed to cases in which patients died before they reached the hospital) and results cannot be generalized to the rest of the country. The authors of these studies nonetheless believe that these observations indicate a strong association between smoke-frec policies and reduced incidence of cardiac arrest (Sargent et al. $2004)$.

Experts also believe that workplace hans encourage smokers, both employees and clients, to either cut down on the number of cigarettes consumed or to quit smoking entirely. One study, using data from the U.S., Canada and Germany, estimates a mean reduction of about 1.3 cigarettes per smoker per day. This rate translates to a 29 percent reduction in overall consumption (Fichtenbery and Clantz 2002). Similarly, internal research by the tobacco industry reveals that smokers who work at job sites that restrict tobacco use smoke one to one-and-a-quarter fewer cigarettes a day. In other words, workplace smoking restrictions cause nearly seven billion fewer cigarettes to be smoked each year (Tobacco Institute n.d.). A 1992 Phillip Morris internal memo also suggests that workplace bans would decrease overall consumption by 8.7 to 10.1 percent. The memo concludes that the laws would also help smokers to quit; it predicted that the cessation rate would rise from 2.5 to 4.4 percent, a 74 percent increase (Heironimus 1992).

The combined health benefits from reduced ETS exposure and cigarette consumption would save millions in health care costs. One Stanford University study estimates that nationwide smoking bans would save $\$ 280$ million over a seven-year period (Williams 2004). Total savings may be even more dramatic. If economic losses due to ETS cost the nation almost $\$ 10$ billion annually (as calculated by the Society of Actuaries), then adopting a nationwide smoke-free policy would likely result in billions of dollars saved each year (Behan et al. 2005). These studies link workplace smoking bans with decreased smoking rates, demonstrate how such bans would decrease ETS exposure and indicate how the bans could yield billions of dollars in health cart savings. 
The Economic Argument: Busi-

NEss Revenues UnHaRmed By

SMOKE-FREE Legislation

Despite the potential savings associated with comprehensive smoking bans, opponents often claim that bans will have a negative impact on business revenues, For example, hospitality industry groups claim that they will lose customers once bans are in force. However, the most rigorous studies have found either no economic impact or an actual improvement in industry business. An early study by Glantz and Smith found that smoking bans had no economic impact on restaurant revenues. The researchers matched California, Utah and Colorado cities with smoke-free ordinances to comparison cities without any smoking restrictions. The cities were similar in population size, income, smoking prevalence and geographic location. No statistically significant differences were found in restaurant or bar revenues (Glantz and Smith 1994). ${ }^{6}$

As momentum for smoke-free legislation builds, more national, state and local governments have enacted these policies, allowing for an analysis of the impact of such bans in diverse jurisdictions. Recent analyses of the smoke-free policies in New York, Delaware, Florida, North Carolina, Massachusetts and New Zealand report positive results. New York City saw an 8.7 percent increase in business tax receipts in restaurants and bars and an additional 2,800 (seasonallyadjusted) bar and restaurant jobs since the implementation of its ban (New York City Department of Finance et al. 2004). An economic impact study presented at the 2004 American Public Health Association's Public Health and the Environment Conference reported the number of restaurant and bar licenses issued in Delaware increased in the year following the implementation of its smokefree law (ANR 2005). In Florida, restaurant sales increased seven percent one year after the passage of its smoking ban, which exempts stand-alone bars (Dai et al. 2004). Another study compared five North Carolina counties with smoke-free laws to comparison counties lacking smoking restrictions (Goldstein and Sobel 1998). Controlling for economic fluctuations, population growth and inflation, it found that there were no economic differences in the restaurant revenues as a fraction of retail sales. Similarly, Harvard University researchers found that Massachusetts' statewide law neither negatively affected revenue and employment in bars and restaurants nor decreased the excise tax totals from meals and alcoholic beverages (Connolly et al. 2005). Lastly, on August 23, 2005, Thomas Kim reported in The Press that an Action on Smoking and Health study found that New Zealand's bar and café patronage remained stable one year after the nation implemented a universal smoking ban. Despite opponents' grim predictions, the hospitality industry continues to flourish in areas that adopt smoke-free legislation.

Like bars and restaurants, other sectors of the hospitality industry have been worried about the economic effects of smoke-free legislation. Despite these concerns, tourism, hotel receipts and gaming revenues do not appear to be suffering in smoke-free areas. One study compared locations with smoke-free ordinances to pre-implementation figures as well as overall measures for the U.S. (Glantz and Charlesworth 1999). No significant changes in the fraction of revenues of retail sales or the rate of change in hotel revenues were observed in this sample. Similarly, the adoption of smoke-free laws by communities in Massachusetts had no effect on bingo parlor profits (Glantz and Wilson-Loots 2003). The authors measured profits as a fraction of taxes on commodities sold, which is similar to reporting restaurant revenue as a fraction of retail sales. They found that although bingo revenues declined, smoking bans could not be the cause of the drop as profits declined steadily (but for one brief early-nineties spike) from 1985 through 2001 (Glantz and Wilson-Loots 2003). Likewise, in a study of the Delaware gaming industry before and after the state adopted a comprehensive indoor smoking ban, researchers found no change on total gaming revenue or average revenue per machine (Mandel et al. 2005). Not unlike bars and restautants, hotels and casinos appear economically unharmed by smoke-free legislation.

Going beyond the studies that analyzed the ban's economic effects on specific localities, some tesearchers have attempted to generalize effects by scrutinizing findings from multiple studies. One team of researchers conducted a thorough search for any and all studies 
assessing the economic effects of indoor smoke-free ordinances. Using criteria established in a 1993 article by Michael Siegal, the authors analyzed the methodologies and findings for each study. Highquality studies met each of the four Siegal criteria: use of objective data, such as tax receipts or employment statistics; inclusion of data points for several periods before and all periods after the policy implementation; use of statistical techniques that control for economic trends and random fluctuations; and control for overall economic trends (Scollo et al. 2003). After using this criteria to review 97 studies on the economic effects of smoke-free laws, these researchers determined that "[a]ll of the best designed studies report no impact or a pasitive impact of smoke-free restaurant and bar laws on sales or employment" (Scollo et al. 2003, 13) (emphasis added). An earlier Canadian study also urged lawmakers to disregard negative economic predictions. The researchers found no evidence of decreased patronage or productivity and consequently recommended that "policymakers should discount industry claims that smoking regulations impose undue economic hardship" (Cremieux and Ouellette 2001, 33). One recent study even suggests that smoke-free laws may actually have a positive economic effect. These researchers found that, controlling for other economic variables, restaurants operating in regions with indoor smoking bans were more profitable. Therefore, when ownership changed hands, the restaurants in smokefree regions sold at a higher price than comparable restaurants without smoking restrictions, with the smoke-free businesses profiting from a median price increase of 16 percent (Alamar and Glantz 2004). The devastating economic losses predicted by opponents of smoke-free laws have simply not materialized.

\section{Arguments Against the Ban: The}

\section{Tobacco Industry Protects ITs}

\section{INTERESTS}

The extensive evidence in support of smoke-free legislation raises the question of why these bans have yet to become universal in the U.S. One explanation for this situation rests in the numerous efforts by the tobacco industry. The industry funded scientific studies showing that ETS is harmless, lobbied for ventilation as an alternative to smoking bans, claimed that smoking bans have a negative economic impact and allied with the hospitality industry in order to bolster its arguments against smoking restrictions and protect its economic interests.

\section{ETS is hatmless}

For years, the tobacco industry funded scientific studies, which argue that second-hand smoke has no proven negative health effects. An analysis of internal tobacco industry documents made public through a 1998 settlement between tobacco companies and the state of Minnesota concluded that the tobacco industry undertook an "expansive campaign to produce scientific research and influence public opinion on the health consequences associated with ETS. . to protect [its] financial and political interests" (Muggli et al. 2001, 1420). Another team of researchers reviewed 106 articles published in medical journals from 1980 to 1995. Thirty-seven percent of these reviews found ETS to be harmless. Of these articles, the tobacco industry funded 74 percent (Barnes and Bero 1998). Controlling for other factors such as year of publication, peer review status and article quality, Barnes and Bero found that an author's association with the tobacco industry was the only statistically significant factor associated with a "not harmful" finding. These analyses reveal that research funded by the tobacco industry has drawn biased and unreliable conclusions.

\section{Ventilation as a compromise}

With increased public visibility of ETS' health hazards in the 1980s and 1990s, tobacco companies attempted to mitigate any effect smoking restrictions might have on smokers' habits and the industry's bottom line by developing a strategy to preempt policies that would address the problem at its source. Thus, the industry began vigotously marketing ventilation as a "compromise" solution to ETS exposure (Drope et al. 2004). At an internal corporate meeting in 1994, Steve Parrish, Phillip Mortis USA's Senior Vice President for Legal and External Affairs, explained:

\footnotetext{
"In terms of general strategy in dealing with ETS, we take every opportunity to shift the focus from ETS to
} 
indoor air quality in generd... by bighlighting the slippery slope argument - showing potential allies in business bow they might be the next victims of EPA's shoddy science [referring to EPA's report on ETS bealth dangers7. In doing so, we bope to discredit the EPA and prevent smoking ban legislation wherever it is proposed. In its stead, we want to encourage the accommodation of both smokers and nonsmokers... and promote the adoption of ventilation standarls." - (Parrish 1994, 19)

As Mr. Parrish described, tobacco companies continued to lobby ASHRAE decision-makers throughout the 1980s and 1990s. In 1981, the American Society of Heating, Refrigeration and Air Conditioning (ASHRAE), the body that develops and sets ventilation standards in the United States, declared tobacco to be "sone of the most difficult contaminants to control at the source"' and developed a stringent standard (621981) that did not "impair health"' (Bialous and Glantz 2002, 316). Standard 62-1981 would have acknowledged that ETS was not just a minor odor problem, but rather a real health risk. This admission, coupled with more stringent ventilation standards, would have negatively affected tobacco sales. Fearing this outcome, the tobacco industry successfully appealed Standard 62-1981, preventing its implementation (Bialous and Glantz 2002).

The ASHRAE deliberation of a revised standard (62-1989) in 1989 further evidenced the tobacco industry's influence on ventilation regulations. During the debate of Standard 62-1989, ASHRAE excluded the president of the Massachusetts Group Against Smoking Pollution (GASP), Richard Daynard, out of fear that he would "just gum up the works" and prevent consensus (Bialous and Glantz 2002, 316). This one-sided discussion resulted in regulation preferred by the tobacco companies. In subsequent years, tobacco representatives sat on ASHRAE committees and met with the board of directors, eventually winning a "continuous maintenance" designation for Standard 62-1989 that allowed them to exercise significant control over its content (Bialous and Glantz 2002). A Phillip Morris executive described this designation as a "major victory" and claimed that ASHRAE had "heard and recognized" the tobacco companies" position (Bialous and Glantz 2002, 321).

In 1999, despite the continued efforts of the tobacco companies, ASHRAE published a more stringent indoor air quality standard. Approved Standard 62-1999 holds that a building that allows smoking cannot be consistent with ASHRAE standards for quality (Bialous and Glantz 2002, 322). That same year, Phillip Morris responded by developing an alliance with the hospitality industry to form the Hospitality Coalition on Indoor Air Quality. Despite heavy lobbying from the Coalition, however, ASHRAE has recently announced that ventilation does not provide adequate protection against harmful ETS health risks. In the summer of 2005, ASHRAE announced that the "adverse health effects for the occupants of the smoking room cannot be controlled by ventilation" (ASHRAE 2005).

Before ASHRAE announced that ventilation could not mitigate the adverse health effects of ETS, its experts claimed that high-quality ventilation systems could significantly reduce indoor ETS levels (Repace 2000). To prove that ventilation still left workers at risk, Repace modeled ventilation systems' effects on second-hand smoke. Under ideal mechanical conditions, ETS subject to "dilution ventilation," the most common system in the U.S., results in a combined risk for cancer and heart disease ranging from 15 to 25 per 1000 workers. This level exceeds the "acceptable risk" level for federally regulated toxic substances by 15,000 to 25,000 times. Assuming that more rigorous ventilation could reduce ETS levels by 90 percent (as asserted by the ASHRAE panel of experts), the study found that the combined risk for workers was still 1.5 to 2.5 per 1000 people, or 1500 to 2500 times the "acceptable risk" level. Even rigorously maintained ventilation systems using the best (and therefore most costly) technology do not eliminate the elevated health risks faced by bar and restaurant employees (Repace 2000).

\section{Negative economic impact of smoke-free}

\section{legislation}

Having lost the public health battle, the tobacco industry has waged a new counter-campaign by hiring consultants to find negative economic consequences of smoke-free legislation. In the extensive meta-analysis conducted by Scollo et al, discussed earlier, the authors found that of the 35 studies reporting negative economic results, 94 percent were funded by the tobacco industry or organizations affiliated with 
tobacco companies (Scollo et al. 2003). They observed that each of these studies failed to meet "more than one of Sicgel's other three criteria for methodological quality" (Scollo et al. 2003, 15). Moreover, the meta-analysis indicated that 80 percent relied only on subjective measures such as anecdotal reports or polls of industry owners or patrons rather than on objective data collected by an independent agency. These studies were also 20 times less likely to have been peer-reviewed than research finding no economic effects. In fact, only one of these "negative" studies was peer-reviewed; it also relied on subjective measures and was funded by the tobacco industry ${ }^{7}$

In addition to lacking sound methodology, the tobacco industry-funded studies might purposefully misrepresent economic data. For example, the American Lung Association (ALA) describes a 2004 tobaccofunded study conducted by Ridgewood Associates that claimed 2,650 jobs and $\$ 71.5$ million in worker earnings were lost as a direct result of New York's statewide smoke-free legislation (ALA 2004). When Alamar and Glantz (2004) replicated the study with the same economic data, they found that New York actually gained 1,500 jobs and $\$ 29$ million in worker earnings. Alamar and Glantz also criticize a 1990 study sponsored by Phillip Morris (now Altria) that based its negative economic findings on a survey of bat and restaurant owners' predicted impacts of an indoor smoking ban (Alamar and Glantz 2004). These examples, together with the Scollo et al. meta-analysis, indicate that the tobacco industry might be manipulating studies in order to persuade the hospitality industry and lawmakers that smoke-free laws damage profits. The tobacco industry's internal documents reveal that as early as 1994 , its economic studies were mere scare tactics. Phillip Morris employee David Laudner stated,

"The economic arguments often used by the [tobacco] industry to scare off smoking ban activity are no longer working, if indeed they ever did. These arguments simply bad no credibility with the public, which isn't surprising when you consider our dire predictions in the past rarely came true."

- (Walls 1994, 28)

\section{Alliance with the hospitality industry}

The tobacco industry's claims thatETS is harmless and that ventilation provides an acceptable solution to the problem of ETS exposure have been fully refuted. Despite being unable to prove that smoke-free legislation damages revenues and profits, the tobacco industry continues to build relationships with the hospitality industry to block smoking bans. Internal Phillip Morris documents reveal its efforts to court the hospitality industry as an ally to defeat smoking restrictions. An undated Phillip Morris presentation argued that the company needed "to build a strong and relevant relationship with the hospitality industry" (Phillip Morris USA n.d., 3) (emphasis in original). Once the hospitality industry was convinced that smoking bans were economically damaging, tobacco companies could collaborate with local interest groups to preempt legislation. In at least one instance, the tobacco industry formed its own "hospitality" front group. When the California restaurant industry supported the proposed universal smoking ban, Phillip Morris created its own coalition outside the group to bolster opposition to the measure (Walls 1994).

Many bar and restaurant owners base their opposition to smoke-free laws on industry rumors. Opponents claim smoke-free laws would have unwanted consequences for both businesses and neighborhoods. These assertions generally lack any objective evidence and primarily consist of anecdotes, gossip and speculation about various ways in which these laws will unfavorably change the behavior of smokers. For instance, one scenario envisions increased noise and street pollution due to smokers congregating outdoors. Other industry opponents fear that smoking patrons would leave without paying for their meals. Or, having paid for their dinner, patrons leaving to smoke would decide not to step back inside for the additional drink they might have otherwise consumed had they remained in their seats. Finally, in areas that border cities or states without smoke-free ordinances, some opponents speculate that smokers will flee the jurisdiction to pattonize neighboring bars that allow indoot smoking. While the evidence indicates that this latter situation is not damaging over the long run, policymakers can mitigate any individual effects by adopting a broad-based regional approach to smokefree policy. Although some of these concerns may be valid in the short run, their potential long-term harm has been overstated. In the short-term, a market adjustment will likely occur. Some businesses might 
observe a temporary drop in sales. However, all credible studies of the aggregate data show that smoking bans do not hurt industry profits. Moreover, these hypothetical minor consequences hardly overtide the public health, equity and economic benefits provided by smoke-free policies.

\section{Political Feasibility: Policymakers}

\section{Act Despite Special Interests'}

\section{EFFORTS}

The public recognizes the danger of second-hand smoke. A 2001 Gallup poll asked Americans to describe the harmfulness of second-hand smoke to adults; 85 percent responded that ETS is "very" or "somewhat" harmful (Gallup 2001). " Support for banning ETS also continues to grow. In 1987 , only 17 percent of respondents believed smoking should be banned in restaurants (Gallup 1987). By 2005, 54 percent supported restaurant smoking bans (Gallup 2005). A 2004 poll asked, "Would you favor or oppose a ban on smoking in your state that would make it illegal to smoke in all workplaces, restaurants and bars?" (Gallup 2004). Fifty-eight percent reported that they would support a smoke-free law (Gallup 2004). Citizens increasingly support smoke-free policies as positive health and economic findings are observed across the country and around the world.

In Washington, D.C., researchers found considerable local public support for smoke-free legislation. According to a poll commissioned by the ACS released in January 2005, 75 percent of likely D.C. voters strongly agreed that all workers should be protected from second-hand smoke, while 10 percent "somewhat" agreed with the statement. Seventy-four percent favored smoke-free policies in all work settings, including bars and restaurants (Lake Snell Perry and Associates 2005). According to Angela Bradbury of the local smoke-free legislation advocacy group Smokeftee DC, grasstoots support for the ban seemed to increase as the public interest group's campaign increased in visibility. ${ }^{9}$ A solid majority of D.C. voters backed a universal ban.

As outlined above, public support for smoke-free legislation is growing stronger. Furthermore, evidence also shows that workplace smoking bans provide equal protection from serious health tisks to all workers, yield healthcare and productivity savings, and exhibit no adverse economic impact on industry revenues or employment. With such an overwhelming rationale for all governments to enact smoke-free policies, why haven't they done so? The involvement of special interest groups, predominantly representing wellfunded business interests, offers one persuasive explanation.

Interest groups form or mobilize when the policy arena is "disturbed." As certain policy problems are identified in the policymaking process, organizations and citizens perceive their interests to be at stake in the proposed solutions (Lowery and Gray 2004). The mobilized group enters the policy process among a throng of other organizations, some of which have competing interests. The group might ally with other organizations, as the tobacco industry has done with the hospitality sector, to strengthen its influence. The group attempts to influence policy outcomes, usually through lobbying or contributing to campaigns. Policy outcomes may or may not reflect the group's advocacy efforts (Lowery and Gray 2004).

As demonstrated by the ETS debate, interest groups might develop close working relationships with the governmental agencies that regulate their industries. Administrative agencies or legislative staff-members, especially at the state level, frequently rely on these groups to provide specialized, technical information (Anderson 1997). Policymakers, constrained by a lack of time and staff, similarly rely on the groups' expertise in complex matters (Anderson 1997). Private groups thus often play a large role in state policy formation. The revolving door between the public and private spheres also increases the power of interest groups (Hamm 1995). Influential members of a committee or agency sometimes leave the public sector to join special interest organizations. Likewise, interest group members occasionally join the very agencies responsible for regulating their former industries (Hamm 1995). The tobacco companies successfully delayed ASHRAE's health-based indoor air quality standard through these roles and relationships with the regulatory body. In this way, the industry not only provided ASHRAE.with information, but also participated directly in policy formulation. In every 
state and municipality considering smoke-free legislation, the tobacco companies enter the debate seeking to maintain the status quo and thwart policy change.

The ETS debate also illustrates how the information that interest groups provide to policymakers is not always reliable. At least one researcher has argued that the public interest suffers when government relies on interest-group-funded "scientific" studies or gives too much weight to a group's challenges to disinterested scientific research (Wagner 2005). Through procedures designed to give stakeholders greater voices, ${ }^{10}$ interest groups have increasingly been able to present "objective" studies that support their positions. The scientific community requires transparent reporting and peer-review processes in order to maintain rigorous standards of objectivity and quality in scientific research. Wagner explains that interested groups can "conduct endsoriented research, replete with undisclosed methodological and design decisions selected precisely because they produce a desired, predetermined result" (Wagner 2005, 99). As researchers have shown, the tobacco industry has funded such "ends-oriented" studies for decades. The industry then offers these findings as legitimate evidence in the public smoking debate.

As interests groups expand their ability to formally challenge established studies, they are equipped to oppose policy judgments while portraying their arguments as objections to the underlying science. Wagner writes that interest group grievances "that purport to challenge the validity of agency science similatly take issue, at least in part, with the agency's value judgments or policy extrapolations adopted within the context of a large risk assessment" (Wagner 2005, 103). Indeed, when the EPA announced in 1994 that it had classified ETS as a Class A carcinogen, the tobacco industry immediately challenged the decision on just these grounds. The industry objected to both the agency's decision to use a 90 percent confidence level for statistical significance and its reliance on home (rather than workplace) based studies to support its conclusions (EPA 2005). The tobacco industry waged a media campaign dismissing the EPA report as "junk science" despite the overwhelming evidence that ETS posed severe health risks to all citizens (Sarnet and Burke 2001). While federally-sponsored scientific research should certainly be subjected to objective peer scrutiny, giving the same weight to interest groups' criticisms may not further the public good.

\section{The Washington, D.C. Experience ${ }^{11}$}

The tobacco industry has lobbied against smokefree laws in every state and municipality. This powerful faction claims to represent the hospitality industry's interests, but its efforts surely reflect the tobacco industry's own agenda. Interest groups have fought to keep universal bans off the books and their efforts have been rewarded all too often. The ETS debate in Washington, D.C. illustrates the clash of competing interests in the policymaking process.

From 2003 to 2005, the restaurant lobby in Washington, D.C. successfully thwarted smoke-free measures through both political pressure and litigation. District restaurants were convinced that a smoking ban would lead to lost customers and decreased revenue. A representative for the Restaurant Association of Metropolitan Washington (RAMW) asserted that a smoking ban would also harm the city, as it would "adversely [affect] the sales tax and cigarette tax revenues collected by the District" (RAMW 2004). Armed with these arguments, the interest group prepared to defeat any efforts to bring smoke-free policies to public debate. A measure to ban smoking in city bars and restaurants was introduced in 2003 but died in committee in the D.C. Council, reportedly after heavy lobbying by the restaurant industry. The next year, RAMW filed a lawsuit against a 2004 initiative that would have placed a referendum on a citywide workplace smoking ban on the November ballot. The lawsuit succeeded in May 2004 when a D.C. Superior Court judge struck down the initiative (RAMW 2004).

In January, Councilmember Adrian M. Fenty revived the issue by introducing the Smoke-free Workplaces Act of 2005 (Fenty et al. 2005). Like the defeated 2003 proposal, it was referred to the Environment and Public Works Committee, chaired by Republican member-at-large Carol Schwartz (D.C. Council LIMC n.d.). Councilmember Kathy Patterson introduced a second bill in May 2005 designed to circumvent Schwartz's committee. This bill specifically amended the functions of D.C.'s Department of Health to include enforcement of an indoor smoking 
ban (Patterson et al. 2005). The bill was referred to the Health Committee, chaired by Councilmember David Catania (D.C. Council LIMC n.d).

In response, Councilmember Schwartz, a restaurant industry ally and the ban's most vocal opponent, introduced a "compromise" bill that provided businesses with tax incentives to adopt a smoke-free policy, but did not ban smoking altogether (Schwartz 2005a). In an op-ed published in The Wasbington Post on May 29, 2005, she argued that there are over 200 smoke-free dining options in the District. This number, however, includes fast food restaurants, delicatessens, and other establishments that do not sell alcohol or employ wait staff to serve customers, as pointed out by Angela Bradbury of Smokefree DC. ${ }^{12}$ Ms. Schwartz thus overstated the true options available for smoke-free experiences in restaurants and bars.

The Council held public hearings in the summer of 2005. Patterson's measure eventually passed the D.C. Council in an initial vote of 12-1 vote on December 5, 2005. On January 5, 2006, the bill passed in a final 11-1 vote. Schwartz was the only member to vote against the bill. As Michael Niebauer reported in the D.C. Examiner on June 13, 2005, D.C. Mayor Anthony Williams reconsidered his initial opposition to the ban in June 2005 after an analysis of smokefree legislation in nearby Montgomery. County, Maryland showed no adverse economic impact. By December, however, Mayor Williams once again opposed the measure and contemplated vetoing the legislation. The overwhelming Council support for the measure, as indicated by the final vote tally, suggested that members would have overridden a mayoral veto. Perhaps for this reason, Mayor Williams did not veto the bill in the ten days following the final vote. As Congress did not pass a joint resolution of disapproval, which requires the President's signature, within 30 days of the Act's passage, the law stands (Council of the District of Columbia n.d.). The Associated Press reported on April 2, 2006 that the D.C. ban would go into effect for all indoor public spaces except bars and nightclubs the following day. The article also noted that these establishments will have to be smoke-free beginning January 1, 2007.

The restaurant industry, however, did not suffer a complete loss. The bill gives the mayor discretion to waive compliance for any businesses that can show "undue financial hardship" (D.C. Council 2006). This vague language provides policymakers and businesses with a loophole; the extent of its usage will likely depend on the presiding mayor's political philosophy. No indication has been given that the Council will establish an objective yardstick to determine what comprises an "undue financial hardship" or how long after implementation the mayor will entertain hardship claims. The bill exempts tobacco and hookah shops as well as establishments that can show that 10 percent or more of its annual revenue stems from tobacco sales, excluding cigarette machines (D.C. Council 2006). While smoke-free advocates would prefer to close the loophole, D.C.'s experience shows that policymakers can overcome interest groups' preemptive roadblocks and act to protect their constituents from second-hand smoke.

\section{CONCLUSION}

The toxins and carcinogens in second-hand smoke deeply penetrate the lungs and substantially increase the risk of developing cancer, heart disease and respiratory conditions. As such, ETS costs American society billions of dollats in health care costs and lost productivity. No safe exposure level to ETS exists. Therefore, policy alternatives requiring highperformance ventilation or structurally separate smoking areas would not sufficiently protect worker health. Only a universal indoor ban corrects the disparate impact of traditional smoking restrictions and eliminates the problem at its source.

Eliminating ETS through a comprehensive workplace smoking ban does not cripple the hospitality industry or the economy. Rigorous studies of areas that have adopted smoke-free laws have either demonstrated no economic impact or have observed positive economic results. Opponents' objections to smoking bans are either based on mere speculation or are supported by poorly designed studies - funded by the tobacco industry - that rely on subjective measures or industry surveys and predictions. As internal documents from the industry reveal, tobacco companies have conspired for decades to prevent legislation that could decrease their profits. First, they denied the harm caused by ETS. Later, they promoted 
ventilation as a "solution" to the problem. Now, the tobacco companies are circulating rumors and faulty studies predicting economic ruin. While smoke-free policies have gained momentum, such special interests continue to pose significant obstacles to legislation, as illustrated by RAMW's efforts in the District of Columbia.

All citizens have the right to workplace protection from toxic substances, regardless of socioeconomic status or their chosen employment. Bar and restaurant employees should not, as opponents often suggest, have to choose between exposure to carcinogens or finding another job. The benefits to society outweigh any inconvenience to individual smokers. Not only do smoking bans bring about benefits in the form of dollars saved through decreased health care costs and increased productivity, but they also provide benefits not necessarily measured in the marketplace, including greater public health and equitable protection from dangerous working conditions for all citizens. Policymakers must take immediate action to ensure that all Ameticans can pursue their livelihoods without compromising their health.

\section{NoTES}

${ }^{1}$ California mandated smoke-free dining in 1995 and smoke-free bats in 1998 (California Department of Health Services n.d.).

${ }^{2}$ Other federal agencies have also recognized ETS as a carcinogen. Beginning in 2000, the National Toxicology Program (of HHS) has included ETS in its Report on Carcinogens listing ETS as a "known" carcinogen (HHS 2005a). According to HHS, known carcinogens point to a causal relationship between contact with the agent, substance, or mixture and human cancer (HHS 2005b). Under the CDC, the National Institute for Occupational Safety [NIOSH] reported the link between ETS and cancer in 1991 (CDC 1991), and NIOSH lists ETS in its compilation of potential occupational carcinogens (CDC n.d.).

${ }^{3}$ The median wage for food preparation and service workers is $\$ 7.06$ per hour (U.S. DOL 2005).

${ }^{4}$ Lack of data prevented the researchers from estimating the latter category.
${ }^{5}$ Researchers defined lost productivity as lost wages, lost fringe benefits, and lost household services. To find the latter value, the authors use an estimate for the average number of hours of unpaid household services $(1,200$ hours per year) that they multiply by the current federal minimum wage, estimating that $\$ 6,180$ in household services is lost per year per person. Because ETS-related conditions generally occur later in life, they used data only for individuals with no children under age eighteen (Behan et al. 2005, 22).

"Although the originally published paper contained some errots regarding the implementation dates for certain cities, the researchers replicated the work with corrected onset dates and updated data. Their revised study found that correcting these dates had no effect on their original conclusions and that the additional data only bolstered their 1994 findings (Glantz and Smith 1997).

${ }^{7}$ Scollo and Lal (2005) have continued to update this analysis after its original publication date, and their findings are unchanged as of July 2005 , the date of the latest revision.

${ }^{8}$ Fifty-two percent describe ETS as "very harmful" and 33 percent describe it as "somewhat" harmful (Gallup 2001).

${ }^{9}$ Angela Bradbury, personal communication to author, January 7, 2006.

${ }^{10}$ The Supreme Court's Daubert v. Merrell Dow Pharmaceuticals, Inc. in 1992 revised the Frye standard, the longstanding criterion for admissibility of scientific evidence requiting "general acceptance in the scientific community." Judges assess the validity and reliability of scientific testimony submitted by interested parties. In the administrative arena, the Data Access Amendment of 1999 and the related Data Quality Act require interested parties access to underlying data in federallysponsored scientific studies and provides a formal procedure for parties to challenge these studies' quality (Wagner 2005, 100).

${ }^{11}$ The author compiled this narrative of the Washington, D.C. smoking ban legislation from several articles by Eric Weiss published in the Washington Post between March 15, 2005 and January 5, 2006.

${ }^{12}$ Angela Bradbury, personal communication, January 7, 2006 . 


\section{REPERENCES}

† These articles are also available at http://wrww.tobaccoscam.org.

Alamar, B. C., and S. A. Glantz. 2004. Smoke-free ordinances increase restaurant profit and value. Contemporary Economic Policy 22(4): 520-525. ${ }^{\dagger}$

American Cancer Society (ACS). 2004. Secondhand s moke.http:// ww w. cancet.org/ doc root/PED/content/ PED_10_2X_Environmental_Tobacco_SmokeClean_Indoor_Air.asp (accessed May 25, 2005).

2005. The facts about secondhand smoke. http://www.cancer.org/docroot/COM/content/ div_TXCOM_11_2x_The_Facts_about_Secondhand_Smokeasp ?sitearea=COM (accessed May 31, 2005).

American Cancer Society, American Lung Association, American Heart Association and Campaign for Tobacco-Free Kids. 2004. Disparity in protecting food service employees from secondhand smoke underscores need for comprehensive smoke-free policies.http:// tobaccofreekids.otg/ Script/DisplayPressRelease.php3?Display $=743$ (accessed May 25, 2005).

American Lung Association (ALA). 2004. Furzy matb: How the tobacco industry distorts the truth about the economic effects of smokefree restaurants and bars. New York: ALA. http:/ /www.lungusa.org (accessed January 7, 2006)

Americans for Nonsmokers' Rights (ANR). 2005. Economic impact of smokefree lans: Case studies. May. Berkeley, CA: ANR. http://www.no-smoke.org/ (accessed January 8,2006 ).

America Society of Heating, Refrigeration, and Air Conditioning Engineers (ASHRAE). 2005. ASHRAE ETS position document: Engineers sbould follow local codes in regard to smoking. August 5. Atlanta, GA: ASHRAE. http://www.ashrae.org/ (accessed January 24, 2006).

Anderson, J. E. 1997. Public Policymaking 3d ed. New York: Houghton Mifflin.

Associated Press. 2006. D.C. smoking ban takes effect on Monday. Associated Press, April 2.
Barnes, D. E., and L. A. Bero. 1998. Why Review Articles on the Health Effects of Passive Smoking Reach Different Conclusions. Journal of the American Medical Association 279(19): 1566-1570. ${ }^{\dagger}$

Behan, D. R., M. P. Eriksen, and Y. Lin. 2005. Economic effects of environmental tobacco smoke report. Report prepared by the Society of Actuaries. March 31 . h t t p : / / w w w. soa.org/ c c m/ content/areas-of-practice/life-insurance/research/ economic-effects-of-environmental-tobaccosmoke-SOA (accessed January 7, 2006).

Bialous, S. A., and S. A. Glantz. 2002. ASHRAE Standard 62: Tobacco industry's influence over national ventilation standards. Tobacco Control 11:315 328.

British Broadcasting Corporation. 2005. Passive smoking 'blindness risk'. BBC, December 20.

Buss, S. E., and J. Rusinko. 2005. Press Release: Restaurant workers more at risk for secondhand smoke. University of Minnesota Academic Healtb Center, May 10.

California Department of Health Services. 2005. Indoor and outdoor secondhand smoke exposure. www.dhs.ca.gov/tobacco/documents/pubs/ SecondHandSmoke.pdf (accessed February 15, 2006).

Connolly, G. N., C. Carpenter, H. R. Alpert, and M. Skeer. 2005. Evaluation of the Massachusetts Smoke-free Workplace Law: A preliminary report. Presentation to Harvard School of Public Health Tobacco Control Working Group, April 4, in Boston, Massachusetts.http:// www. hs ph. harvard.edu/php/pri/ tcrtp/Smoke-free_Workplace.pdf (accessed January 8,2006 ).

Council of the District of Columbia (D.C. Council). How a bill becomes a law. Also available online at http://www.dccouncil.washington.dc.us/ (accessed February 13, 2005).

2006. Department of Health Functions Clarification Act of 2006. http:// www.dccouncil.washington,dc.us/images/00001/ 20060113145752.pdf (accessed January 30, 2006). 
Council of the District of Columbia Legislative Information Management Center (D.C. Council LIMC). http://www.dccouncil.washington.dc.us/ lims/default.asp (accessed July 1, 2005).

Cowell, A. 2006. Btitish ban indoor smoking. The New York Times. February 15.

Cremieux, Pierre-Yves, and P. Ouellette. 2001. Actual and perceived impacts of tobacco regulation on restaurants and firms. Tobacco Control 10: 33-37.

Dai, C., D. Denslow, A. Hyland, and B. Lotfinia. 2004. The economic impact of Florida's Smoke-free Workplace Law. Bureau of Economic and Business Research, Wartington College of . Business Administration. Gainesville, Florida: University of Florida. http://www.smokefreeforhealth.org/pdf/ economic\%20study.pdf (accessed January 22, 2006).

Drope, J., S. A. Bialous, and S. A. Glantz. 2004. Tobacco industry efforts to present ventilation as an alternative to smoke-free environments in North America. Tobacco Contral 13: 41-47.

Eisner, M. D., A. K. Smith, and P. D. Blanc, 1998. Bartenders' respiratory health after establishment of smoke-free bars and taverns. Journal of American Medical Association 280: 1909-1914.

Fenty, A. M., K. R. Brown, V. C. Gray, P. Mendelson, and K. Patterson. District of Columbia City Council. 2005. Smokefree Workplaces Act of 2005, Proposed legislation. http:/ www.dccouncil.washington.dc.us/ images/00001/20050314120806.pdf (accessed July 1, 2005).

Fichtenberg, C. M., and S. A. Glantz. 2002. Effect of smoke-free workplaces on smoking behavior: A systematic review. British Medical Journal 325: 188.

Gallup Poll. 1987. Roper Center at University of Connecticut. What is your opinion regarding smoking in public places? Public Opinion Online. December (accessed February 11, 2005).

2001. Roper Center at University of Connecticut. In general, how harmful do you feel second-hand smoke is to adults? Public Opinion Online. September 29 (accessed June 9, 2005).
2004. Roper Center at University of Connecticut. Would you favor or oppose a ban on smoking in your state that would make it illegal to smoke in all workplaces, restaurants and bars? Public Opinion Online. September 29 (accessed February 11, 2005).

2005. Roper Center at University of Connecticut. What is your opinion regarding smoking in public places? Public Opinion Online. July 20 (accessed February 11, 2005).

Gallus, S., P. Zuccaro, P. Colombo, G. Apolone, R. Pacifici, S. Garattini, and C. La Vecchia. 2005. Effects of new smoking regulations in Italy. Annals of Oncology 17(2): 346-347.

Glantz, S. A., and A. Charlesworth. 1999. Tourism and hotel revenues before and after passage of Smokefree Restaurant Ordinances. Journal of the American Medical Association 251(20): 1911-1918.

Glantz, S. A., and L. Smith, 1994. The effect of ordinances requiring smoke-free restaurants on restaurant sales in the United States. American Journal of Public Health 84: 1081-85.

1997. The effect of ordinances requiring smoke-free restaurants and bars on revenues: $A$ follow-Up. American Journal of Public Health 87(10): 1687-1081. ${ }^{\dagger}$

Glantz, S. A., and R.. Wilson-Loots. 2003. No association of Smoke-free Ordinances with Profits from Bingo and Charitable Games in Massachusetts. Tobacco Control 12: 411-413.

Goldstein, A. O., and R. A. Sobel. 1998. Environmental Tobacco Smoke Regulations Have Not Hurt Restaurant Sales in North Carolina. Nortb Carolina Medical Journal 59: 284-287.

Hamm, K. 1995. Patterns of influence among committees, agencies, and interest groups. In Public Policy Theories, Models and Concepts: An Anthology. Edited by Daniel McCool. Englewood Cliffs, New Jersey: Prentice Hall.

Heironimus, J. 1992. Impact of the workplace restrictions on consumption and incidence - Internal document. Bates Number 2023914280/4284. 
Phillip Morris USA. http://legacy.library.ucsf.edu/ $\mathrm{cgi} / \mathrm{getdoc}$ tid $=\mathrm{rvv} 24 \mathrm{e} 00 \& \mathrm{fmt}=$ gif $\&$ ref $=$ results $\&$ itile $=$ IMPACT $\% 200 \% \% 20$ WORKPLACE $\% 20$ RESTRICT IONS $\% 200 N \% 20$ CONSUMPTION $\% 20$ AND $\%$ 20INCIDENCE\&bates $=2023914280 / 4284$

(accessed February 12, 2006).

International Agency for Research on Cancer (IARC). 2002. IARC monographs on the evaluation of carcinogenic risks to humans: Vol. 83 (Tobacco Smoke and Involuntary Smoking).

Kim, T. 2005. Smoking ban fails to affect bar patronage. The Press, August 23.

Koch, W. 2005. 39\% live in areas that limit smoking. USA Today, December 28.

Lake Snell Perry and Associates. 2005. Voters in Washington DC speak out on smoke-free workplaces, restaurants and bars. http:// www.lspa.com/polls/pdf/ACSCAN.pdf (accessed June 12, 2005).

Lowery, D., and V. Gray. 2004. A neopluralist perspective on research on organized interests. Political Research Quarterly 57(1): 163-175.

Mandel, L. L., B. C. Alamar, and S. A. Glantz, 2005. Smoke-free law did not affect tevenue from gaming in Delaware. Tobacco Control 14: 10-12.

Muggli, M. E., J. L. Forster, R. D. Hurt, and J. L. Repace. 2001. The smoke you don't see: Uncovering tobacco industry scientific strategies aimed against environmental tobacco smoke policies. American Journal of Public Healtb 91(8): 1419-1123. ${ }^{\dagger}$

National Cancer Institute (NCI). 2005. Secondhand smoke: Questions and answers. February 22. http:/ /cis.nci.nih.gov/fact/10_18.htm (accessed May 31, 2005).

New York City Department of Finance, New York City Department of Health and Mental Hygiene, New York City Department of Small Business Services, and New York City Economic Development Corporation. 2004. The state of smoke-free New York City: A one-year review.
Niebauer, M. 2005. Mayor Williams reconsiders position on smoking ban. The Wasbington Examiner, June 13.

Radio Telefis Éireann. 2004. New Zealand introduces new smoking ban. Radio Telefís Éireann News, December 10. http://www.rte.ie/news/2004/1210/ smoking.html (accessed January 7, 2006).

Partish, Steve. 1994. Merlo/Vendor Conf Draft \#3 Internal Document. Bates Number 2044333814/ 3836. Phillip Morris USA. January 14. Also http:// $\mathrm{d} \mathrm{l} \times \mathrm{s}$. c k m. u c s f.e d u / c g i / getdoc?title $=$ none $\&$ bates $=2044333814 \% 2 F 3836 \&$ last $=23 \& \mathrm{pg}=1+\mathrm{of}+23 \& \mathrm{tid}=\mathrm{doq} 55 \mathrm{e} 00 \& \mathrm{fmt}=$ gif $\& \mathrm{ref}=$ http $\% 3 \mathrm{~A} \% 2 \mathrm{~F} \% 2 \mathrm{Fwww}$.tobaccoscam.ucsf.edu $\% 2$ Ftarget $\% 2$ Ftarget_btm.cfm\%23doq55e00\&ref $=13$ (accessed February 12, 2006).

Patterson, K., S. Ambrose, K. Brown, A. Fenty, V. Gray, and P. Mendelson. 2005. Department of Health Functions Amendment Act of 2005, Proposed legislation. District of Columbia City Council. http:/ /www.dccouncil.washington.dc.us/images/00001/ 20050519153538.pdf (accessed July 1, 2005).

Phillip Morris USA. Phillip Morris and the hospitality industry - Internal document. http:// $\mathrm{d} I \times \mathrm{s}, \mathrm{ckm}$. ucs E.e d u / c g i/ getdoc?tid $=\mathrm{ghf} 36 \mathrm{e} 00 \& \mathrm{fmt}=\mathrm{pdf} \& \mathrm{ref}=$ results (accessed February 12, 2006).

Pueblo City-County Health Department. 2005. Ptess release: New study links smoke-free ordinances to fewer heart attacks. Pueblo City-County Health Department, Noverniber 14.

Repace, J. An air quality survey of respirable particles and particulate carcinogens in Boston pubs before and after a smoking ban. Bowie, Maryland: Repace Associates, Inc. http://www.no-smoke.org/doc/ BostonPubCrawlFinal.doc (accessed January 21, 2006).

2000. Can ventilation control second-hand smoke in the hospitality industry? June. Bowie, Maryland: Repace Associates, Inc, http:// www.dhs.ca.gov/ps/cdic/tcs/documents/pubs/ FedOHSHAets.pdf (accessed January 29, 2006).

2004. Respirable particles and carcinogens in the air of Delaware hospitality venues before and 
after a smoking ban. Journal of Occupational and Environmental Medicine 46: 887-905.

Restaurant Association of Metropolitan Washington (RAMW). 2004. Restaurant Association Metropolitan Washington prevails in keeping the smoking ban OFF the November ballot. April 21 . h t t p : / / w w w r a m w org / newsdetail.cfm?news_id=79 (accessed January 8 , 2005).

Reuters. 2006. Bermuda bans smoking in bars and restaurants. Reuters UK, Aptil 1.

Roman, M. 2006. Tough anti-smoking law starts across Spain. The Associated Press, January 1.

Sargent, R. P., R. M. Shepard, and S. A. Glantz. 2004. Reduced incidents of admissions for Myocardial Infarction associated with public smoking ban: Before and after Study. British Medical Journal 328: 977-980.

Sarnet, J. M., and T. A. Burke. 2001. Turning science into junk: The tobacco industry and passive smoking. American Journal of Public Health 91(11): 1742-1744. ${ }^{\dagger}$

Schwartz, C. 2005. Smoke-free Restaurant, Tavern, and Nightclub Incentive Amendment Act of 2005, Proposed legislation. District of Columbia City Council. http://www.dccouncil.washington.dc.us /images/00001/20050519155030.pdf (accessed July 1, 2005).

2005. Compromise on smoking. Editorial. The Washington Post, May 29.

Scollo, M., A. Lal, A. Hyland, and S. A Glantz. 2003. Review of the quality of studies on the economic effects of smoke-free policies on the hospitality industry. Tobacco Control 12: 13-20. ${ }^{\dagger}$

Scollo, M., and A. Lal, 2005. Summary of studies assessing the economic impact of smoke-free policies in the hospitality industry: Includes Studies Produced to July 2005. Melbourne, Austraila: VicHealth Center for Tobacco Control. http:// www.vctc.org.au/tc-res/Hospitalitysummary.pdf (accessed January 8, 2006).
Shopland, D. R., Anderson, C. M., Burns, D. M., and Gerlach, K. K. 2004. Disparities in smoke-free workplace policies among food service workers. Journal of Occupational and Environmental Medicine 46: 4.

Siegel, M. 1993. Involuntary smoking in the restaurant workplace: A review of employee exposure and health effects. Journal of the American Medical Association (JAMA) 270(4): 490-493.

Smoke At Wotk. Fact Sheet 1: Why is passive smoking a health and safety issue? http:// www.smokeatwork.org/factsheet1.htm (accessed March 31, 2005).

Surindran, S. 2004. Effect of public smoking ban in Helena, Montana. Can law really make a difference? [Letter to the Editor]. British Medical Journal 328: 13791380 .

Szabo, L. 2005. Ireland's smoking ban reaps benefits. USA Today, October 18.

Tobacco Institute. Internal document. Bates numbers TIMN 0014554-14565. Also available online at http:/ / w w w to b a c coinstitute.com/ getallimg. asp?DOCID =TIMN0014554/ 4565\&if=avtidx (accessed July 1, 2005).

Tulunay, O. E., S. S. Hecht, S. G. Carmella, Y. Zhang, C. Lemmonds, S. Murphy, and D. K. Hatsukami. 2005. Urinary metabolites of a tobacco-specific lung carcinogen in nonsmoking hospitality workers. Cancer Epidemiology Biomarkers \&or Prevention 14: 1283-1286.

United States Center for Disease Control (CDC). National Institute for Occupational Safety. NIOSH Carcinogen list. http://www.cdc.gov/niosh/ npotocca.html (accessed February 15, 2006).

. National Institute for Occupational Safety. 1991. Current Intelligence Bulletin 52: Environmental Tobacco Smoke in the Workplace. June. http:// www.cdc.gov/niosh/91108_54.html (accessed February 15, 2006).

2002. Annual smoking-attributable mortality, years of potential life lost, and economic costs - 19951999. Morbidity and Mortality Weelely Report 51(14): 300303. 
2004. Indoor air quality in hospitality venues before and after implementation of a Clean Indoor Air Law - Western New York, 2003. Morbidity and Mortality Weekly 53(44): 1038-1041.

United States Department of Health and Human Services (HHS). 1986. The health consequences of involuntary smoking: A report of the Surgeon General [Electronic version]. Washington D.C: HHS. http://www.cdc.gov/tobacco/sgr/sgr_1986/ index.htm (accessed May 31, 2005).

2005a. Report on carcinogens: Eleventh Edition. Washington, D.C. HHS, http:// ntp.niehs.nih.gov/ntp/roc/toc11.html (accessed May 25, 2005).

2005b. Questions and answers about the $\mathrm{r}$ [eport] o[n] c[arcinogens]. http://ntp.niehs.nih.gov/ go/150 (accessed June 12, 2005).

United States. Department of Labor, Bureau of Labor Statistics (DOL). 2005. Food and beverage serving and related workers. December 20. http:// www.bls.gov/oco/ocos162.htm (accessed January 24, 2006).

United States Environmental Protection Agency (EPA). 1992. Respiratory health effects of passive smoking: Lung cancer and other disorders. http:// cfpub.epa.gov/ncea/ (Accessed June 10, 2005).

1994. Setting the record straight: Secondhand smoke is a preventable health risk (EPA Document Number 402-F-94-005). June. http:// www.epa.gov/smokefree/pubs/strsfs.html (accessed May 31, 2005).

2005. Allowance trading basics. May 12. http:/ /www.epa.gov/airmarkets/trading/basics/ (accessed June 12, 2005).

USA Today. 2004. Study: Air worse in smoky bars than on truck-choked roads. USA Today, September 20.

Wagner, W. 2005. The perils of relying on interested parties to evaluate scientific quality. American Jozmral of Public Health 95(51): 99-106.
Walls, T. 1994. CAC Presentation \#4 - Draft. Bates Number 2041183751/3790. July 8. http:// d $1 \times \mathrm{s}$. c k m. u c s f.e d u / c g i / getdoc?title $=\mathrm{CAC}+\mathrm{PRESENTATION}+\mathrm{NUMBER}+4$ $+\mathrm{T} \mathrm{I} \mathrm{N}+\mathrm{W}$ A L L S + + INTRODUCTION\&bates $=2041183751 \% 2 \mathrm{~F} 3790 \&$ last $=40 \& \mathrm{pg}=1 \& \mathrm{tid}=\mathrm{vnf} 77 \mathrm{e} 00 \& \mathrm{fmt}=$ gif $\& \mathrm{ref}=$ http $\% 3 \mathrm{~A} \% 2 \mathrm{~F} \% 2 \mathrm{Fwww}$ tobaccoscam.ucsf.edu $\% 2 \mathrm{~F}$ fake $\% 2$ Ffake_ctb.cfm $\% 23$ vnf77e00\&ref $=28$

(accessed February 12, 2006 from the University of California, San Francisco Legacy Tobacco Documents Library).

Weiss, E. M. 2005. Smoking foes in D.C. gird for second fight. The Wasbington Post, March 15.

2005. Maneuver aids bill to ban smoking in D.C. restaurants. The Wasbington Post, May 18.

- 2005. Smoking ban gaining in D.C. The Washington Post, June 15.

- 2005. In D.C., a round of satire. The Wasbington Post, June 22.

2005. D.C. inches a step closer to becoming smoke-free. The Wasbington Post, December 7.

2006. D.C. smoking ban approved: Mayor weighs veto despite 11-1 Council vote. The Washington Post, January 5.

Whincup, P. H., J. A. Gilg, J. R. Emberson, M. J. Jarvis, C. Feyerabend, A. Bryant, M. Walker, and D. G. Cook. 2004. Passive smoking and tisk of coronary heart disease and stroke: prospective study with cotinine measurement. British Medical Journal 329: 200205. July 24 .

Williams, S. 2004. Health benefits of snuffing out all workplace smoking. Stanford, CA: Stanford University. 